\title{
The Effects of WordWall Online Games (WOW) on English Language Vocabulary Learning Among Year 5 Pupils
}

\author{
Syafiqah Hasram \\ Faculty of Education, Universiti Kebangsaan Malaysia, 43600 Bangi, Selangor, Malaysia \\ M. Khalid M. Nasir \\ Faculty of Education, Universiti Kebangsaan Malaysia, 43600 Bangi, Selangor, Malaysia \\ Maslawati Mohamad \\ Faculty of Education, Universiti Kebangsaan Malaysia, 43600 Bangi, Selangor, Malaysia \\ Md. Yusoff Daud \\ Faculty of Education, Universiti Kebangsaan Malaysia, 43600 Bangi, Selangor, Malaysia \\ Mohd Jasmy Abd Rahman \\ Faculty of Education, Universiti Kebangsaan Malaysia, 43600 Bangi, Selangor, Malaysia \\ Wan Muna Ruzanna Wan Mohammad \\ Faculty of Education, Universiti Kebangsaan Malaysia, 43600 Bangi, Selangor, Malaysia
}

\begin{abstract}
In the effort to upgrade pupils' vocabulary learning experience, the potential of interactive educational games is increasingly explored as supplementary teaching and learning materials. While the eagerness to integrate mobile technology into English language education is noticeable, there is a lack of evidence on Malaysian English as Second Language (ESL) learners' views of the feasibility of online games in vocabulary learning. This study aims to determine the degree of improvement in pupils' vocabulary performance. The quantitative data was analysed using descriptive and dependent t-test analysis. The crosssectional survey was adapted from the ACRS-V model. The questionnaire was distributed to Year 5 pupils from a national primary school in Negeri Sembilan who are using the syllabus of The English Language Curriculum for Primary Schools (KSSR). The findings show a moderate level of Satisfaction, Attention, Relevance, Confidence and Volition. In addition, a paired sample t-test indicates a significant improvement in the pupils' vocabulary scores after using WordWall (WOW) as a vocabulary learning supplementary material. The effect size demonstrated is also larger regarding its effects in behavioural sciences. This study provides important insights as a guide for primary school English teachers in integrating online games as a learning tool for English language learning, especially in developing pupils' English vocabulary repertoire.
\end{abstract}

Index Terms - ESL learners, online game, primary pupils, vocabulary learning

\section{INTRODUCTION}

The online game serves as a continuation from lessons in school, intending to strengthen and support memory with real-life applications. There is a feature in the online game that records each pupil's vocabulary scores and achievements. It supports the currently employed Classroom-Based Assessment in Malaysia education system which takes into consideration pupils' progress in learning via various mediums to reduce exam-oriented assessments. Therefore, the declining proficiency of English language ability among Malaysian pupils and the weak grasp of English vocabulary has been a matter of concern to Malaysian linguists, educationists and policymakers. Many undergraduates possess insufficient vocabulary repertoire and fail to achieve the minimum word level (2000 words) out of five wordlevel (Lateh, Shamsudin \& Abdul Raof, 2018). The word level consists of high-frequency vocabulary which is also used to gauge pupils' capabilities in English communication. The undergraduates' lack of mastery in English writing skills is affected by their vocabulary deficiency mastery and limited ability to use vocabulary effectively for communication purposes (Ashrafzadeh \& Nimehchisalem, 2015).

In addition, there are cases of low vocabulary repertoire among Year 5 pupils' (Wang \& Yamat, 2019) which results in delays for pupils to comprehend reading materials efficiently (Sidek \& Harun, 2015). The traditional teaching methods of vocabulary which are currently employed in most schools are less interesting, ineffective as well as less 
motivating (Mohamad, Sazali \& Salleh, 2018) and often requires pupils to memorize unfamiliar words with paired translations (Nejati et al., 2018). It leads to issues of low vocabulary acquisition among Malaysian pupils. They only develop their listening and writing skills but not their thinking and questioning skills (Chen \& Lee 2018). Consequently, they become passive learners and are often quiet and uninterested in their learning. In line with the concerns highlighted, the World of Words (WOW) online game in WordWall platform can assist and enrich pupils' experience in acquiring English language vocabulary through 200 vocabularies. This game is accompanied by colourful pictures to help retain players' attention, association of words with images, strengthen the memory of spelling as well as support the understanding of word meaning directly and indirectly. The design of the WOW encourages the use of mobile and gamified learning in class as a teaching aid and serves as supplementary material to encourage fun and independent outof-class learning.

On the ground that there is great anticipation for the use of mobile learning in education, it is eminent to take pupils' perceptions towards the ease of use of online educational games into consideration to ensure the effectiveness and successful implementation of online games in education. After all, the game is designed for their language learning. Earlier studies indicate that pupils' acceptance, attitude, and perceptions towards online games are influenced by several factors. Although Fagan (2019) states that enjoyment and performance expectations contribute to the difference in perceptions among pupils, thus far, there are still limited studies conducted in investigating the relationship between these factors with pupils' perceptions of online games in vocabulary learning. Thus, the purpose of this study is to (1) investigate pupils' motivation levels towards using WOW interactive online games in vocabulary learning and (2) examine the effects of WOW interactive online games on pupils' vocabulary development.

\section{LITERATURE REVIEW}

Several studies have recorded teachers' concern over Malaysian pupils' poor recall of vocabulary. They are largely unable to remember the vocabulary they had learned from the previous day (Chong \& Kee, 2019). For instance, if they learn four new words in an hour lesson for the day, generally they will only be able to recall one word during the lesson on the next day. There are also pupils who can recognize the written or oral form of the words but cannot determine the meaning of the words without guidance from the teacher. Afzal (2019) underscores the ineffective teaching practices adopted in vocabulary teaching and learning as one of the factors in Malaysian pupils' poor vocabulary mastery. Some teachers lack techno-literacy and traditional teaching methods are largely unappealing to learners to learn the subject.

The advancement of technological devices and the internet environment has uncovered a multitude of probabilities for pupils of all levels to learn particularly focusing on the new generation of technology-savvy learners. The emergence of Mobile-assisted Language Learning (MALL) is an advancement to language experience through the facilitation and improvisation using mobile devices (Gangaiamaran \& Pasupathi, 2017; Klimova, 2019). In Malaysia and beyond, there is a growing demand to incorporate independent learning using online platforms in teaching and learning (Kessler, 2018; Nasir et al., 2018; Nasir, 2020). The concept of integrating mobile devices in $21^{\text {st }}$ century education has been the interest of many teachers to improve English competency. The Malaysian government facilitates the greater adoption and diffusion of ICT through several initiatives to improve capacities in education fields which is in line with Malaysia Education Blueprint (MEB) 2013-2025. In the 10-years strategic plan of MEB, the goal is to restructure education as future-proof in line with the industrial revolution 4.0 (Niko Sudibjo et al., 2019).

Nejati, Jahagiri and Salehi (2018) suggest that vocabulary is like building blocks of a language. A limited number of them inevitably disrupt pupils' development in other language skills such as listening, speaking, reading and writing. Alqahtani (2015) states in his study that ESL learners majoring in English rely heavily on their vocabulary knowledge rather than their knowledge in other language areas like grammar. Practitioners and researchers acknowledge that vocabulary acquisition is a challenging task, especially for English as a second language (ESL) learners. Afzal (2019) states that non-native speakers of English face problems relating to the meanings of the new words, spelling, pronunciation, correct use of words, guessing meaning through the context and others. Without sufficient vocabulary, ESL learners are more likely to struggle in comprehending common reading materials, understand and apply grammar rules when using the language (Nejati et al., 2018). Sidek and Ab. Rahim (2015) highlight that the issue of poor vocabulary contributes to difficulties in other language skills as lexical knowledge is fundamental for effective communication.

Many scholars define online games in learning as the integration of game thinking and game mechanics (Takahashi 2010; Bakhsh 2016; Chapman \& Rich, 2018). Mobile learning is known to optimize the potential of mobile devices as learning tools in language learning environments (Daud et al., 2015). The rapid global development of mobile technology speeds up the popularity and proliferation of mobile learning in Malaysia. Kung-Teck et al. (2020) reveal that the incorporation of mobile learning into heutagogy teaching instruction is highly advantageous, as it facilitates interactive, versatile, and multi-modal learning via Google Docs, e-Portfolio, Twitter, YouTube, Quizizz and MindMap. Thamilarasan and Ikram (2019) developed a mobile application tutor service called MyMUET as a supplementary learning aid for Malaysian learners sitting for MUET (Malaysian University English Test). Their findings of the survey note that learners agreed that the mobile application tis highly useful for supplementary materials for out-of-class learning. To date, the application of mobile technology in education or 'mobile learning' has been generating interest among academicians. A growing body of literature has recognized that mobile learning is becoming more popular and 
appreciated due to its adaptability in language learning as the younger generation is generally more technology-savvy. Issham et al. (2016) deduce that one of the driving forces behind the utilization of mobile learning in education is the growing use of mobile devices by the current generation of learners. Perrin and Duggan (2015) also note that online games are favourably approved by young pupils, especially among the pupils at the age of 10 to 18 years old.

Andreani and Ying (2019) found that interactive online game has succeeded in enhancing the language learning experience for low proficiency EFL elementary learners. There is an improvement in pupils' English vocabulary skills after the intervention of mobile application in vocabulary learning. Similar studies are also conducted by Govindasamy et al. (2019) and Fazil and Said (2020). The online game integrates thinking and game mechanics to solve pupils' problems and engage them in interactive learning (Bakhsh, 2016; Chapman \& Rich, 2018). Letchumanan et al. (2015) and Azli et al. (2018) studies indicate that pupils' experience more gratification in learning English with mobile games. Game elements are the contributing factors in engaging, motivating and facilitating interest in ESL learners' vocabulary learning experience. Generally, there is no limit to subject areas in vocabulary learning. Pupils must be engaged in taskbased activities whereby they are able to apply the vocabulary in context to learn and retain new words effectively. With functional game elements, pupils are more motivated, autonomous, and prone to develop problem-solving skills as well as being intrinsically motivated. Azli et al. (2018) reinforce that online game facilitates learning experience and the use of online games in class is very beneficial for pupils.

Wordwall is the most suitable game platform for vocabulary practice. It provides a wide selection of game formats that are beneficial and appealing to the target audience; in this context, the primary school pupils. In contrast, it is crucial to select a game that is exciting while effectively meeting the learning goals as there are games with learning advantages but with little fun factor (Jantke \& Hume 2015). Some games are lacking in educational purposes thus are not employable to the learning process with learning goals. A mindful selection of materials for mobile learning is necessary for the efficient incorporation of learning theory into mobile learning that can blend education and entertainment harmoniously and consequently, spur pupils' interest and boost motivation to learn.

Motivation acts as the essential factor that contributes to language learning efficiency (Tanaka 2017; Dornyei, 2007). Online learning often requires learners to be intrinsically motivated as the online environment is dependent on pupils' self-regulation, curiosity and interests. Other factors such as family socioeconomic status (Shereen \& Tang, 2015; Chukwuere, 2017; Hashim et al, 2017; Zakaria \& Mohamad, 2019), races (Tankari, 2018; Kumi-Yeboah \& Yuan, 2017), familiarity with mobile devices (Alzaza \& Abdul Razak, 2011; Roslina Ibrahim et al., 2011; Adams et al., 2018; Fagan, 2019; Uppal \& Ali, 2020) contribute to the motivation of learning English vocabulary.

In contrast, some studies discovered the acceptance of online games is evident among learners in Malaysia regardless of age and capabilities. It is also widely received by teachers who utilize online games due to their benefits in teaching and learning (Hasin \& Nasir, 2021). Since the proliferation of mobile technology in learning, there is a tremendous buzz of using online games to promote learning through their multimedia capabilities. Tertiary learners remark a positive perception and experience towards mobile learning practice and application to deliver courses in higher education (Karim et al., 2018; Deris \& Shukor, 2019; Mohamad et al., 2020). They are Generation Z learners with complex visual imagery as a result of their brains responding to external conditions Rothman (2016). Learners in Malaysia gradually show general acceptance towards online games. Past studies and literature reviews collected indicate that mobile assisted learning provides a fun learning environment, drives learners to actively participate in lessons and is necessary for accommodating learners' increasing interest and competency in technology.

\section{METHODOLOGY}

The research design for the undertaken study is quantitative which focuses on the pupils' perceptions - the experimental study. The sample consists of 121 Year 5 pupils from a national primary school in Negeri Sembilan who are using the current syllabus for primary school, Language Curriculum for Malaysian National Primary Schools (KSSR). They are chosen through convenience sampling, as they are easily accessible to the researcher and generally possessed a similar level of English proficiency, which is low intermediate. They are selected from the three income groups, which are B40, M40 and T20. The term B40 represents the percentage of the country's population of Bottom 40\% who earns RM3,000. M40 is Middle 40\% whose median household is at least RM 6,625 while T20 is Top 20\% whose median household income is at least RM13,148. A questionnaire is used as an instrument. It is adapted from ACRS-V model (Keller, 2016), Mohamad et al. (2020) and the Year 5 KSSR syllabus (Ministry of Education, 2015) to suit the objectives of the study and participants' level. The questionnaire comprised of two parts; Part A which consists of several demographic multiple-choice items and Part B comprised of items to gauge learners' perceptions towards the use of WOW online games in vocabulary learning. There are five motivational components which are Attention, Relevance, Confidence, Satisfaction and Volition.

The questionnaire consists of 30 statements with a 4-point Likert scale response, ranging from strongly disagree to strongly agree, to indicate their level of agreement to various statements. Additionally, the pre and post-test comprised of 30 vocabulary questions that covers six units of vocabulary in the WOW online game introduced in stages. The items in the questionnaire were validated by an English language Excellent Teacher from the school and two senior lecturers who are the experts in the field. They validated in terms of the relevance of the contents in the questionnaire to ensure the language is accurately translated and the contents are relevant to the research questions. The survey was conducted 
by distributing the questionnaire via face-to-face to all the participants. Participants answered the questionnaire, within the time allocated. The questionnaire was distributed to the participants after they completed the six units of the online vocabulary games or known as WOW.

The pilot test was carried out among a different group of Year 5 pupils with similar language proficiency. The researcher assessed four pupils involved in the pilot test to gauge pupils' comprehensiveness towards the format, content and terminology used in the questionnaire. The researchers identified and revised the items before distributing the questionnaire during the actual administration of the questionnaire. The pilot study was also conducted to identify the duration needed for the pupils to complete the questionnaire. The Cronbach Alpha values for all the items were higher than 0.70. It demonstrates an appropriate level of reliability; thus, all 30 items were included in their questionnaire.

The design of WOW is to cater to the needs of designing follow up activities after learning English vocabulary at school. It serves as a supplementary material or tool in pupils' vocabulary learning. The pupils have accessed WOW after school hours. The words incorporated into WOW were categorized into themes according to the units. WOW designed for this study introduces 200 vocabularies to players. The selected vocabularies are adapted from Curriculum and Assessment Standard Document (for Primary School) (DSKP) and textbook for Year 5 pupils. DSKP is a reliable source of reference for all national schools in Malaysia. Thus, the words presented are the must-mastered vocabulary for all pupils in Year 5. Descriptive analysis is used to analyse and concisely present vast quantities of quantitative data. The analysis of the dependent t-test is utilised for pre-tests and post-tests to calculate the difference in pupils' performance before and after the intervention.

\section{FINDINGS}

Out of 121 participants, only 60 participated in the study which yields $49.59 \%$ return rate. The majority of the participants are Malay, which is $75 \%(\mathrm{n}=45)$. The second largest group is the Orang Asal or Indigenous people which makes up $18.3 \%(n=11)$ of the whole population of the study, while, $6.6 \%(n=4)$ of them are Indian. In terms of socioeconomic status, a significant $63.3 \%(\mathrm{n}=38)$ of the participants are from the B40 group, 30\% $(\mathrm{n}=18)$ are $\mathrm{M} 40$, and only $6.6 \%(n=4)$ are from the T20 group. The B40 group refers to the group with a median household income of less than RM4,360. The final variable is the participants' level of familiarity with mobile devices. The data obtained through a survey showed that $38.3 \%$ of the participants $(n=23)$ are highly familiar with mobile devices while $43.3 \%(n=26)$ of the participants are in the medium familiarity group and the low level of familiarity group consist of $18.3 \%$ of the participants $(n=11)$. The participants' level of familiarity with mobile devices is measured by the frequency of using mobile devices, their aptness in handling mobile devices without help and the regularity in using mobile devices for learning and playing games.

TABLE 1

Mean, Standard DeViation, LeVel And Cronbach's Alpha Value Of EACH Construct In ARCS-V Model

\begin{tabular}{|c|c|c|c|c|}
\hline Constructs & Mean & SD & Category & Cronbach's Alpha Value \\
\hline Attention & 3.54 & 0.36 & Good & 0.786 \\
\hline Relevance & 3.51 & 0.50 & Good & 0.718 \\
\hline Confidence & 3.46 & 0.45 & Quite good & 0.805 \\
\hline Satisfaction & 3.64 & 0.42 & Good & 0.507 \\
\hline Volition & 3.35 & 0.50 & Quite good & Overall: 0.775 \\
\hline
\end{tabular}

Referring to Table 1, the construct with the highest value of mean is Satisfaction (Mean=3.64, SD=0.42). Followed by Attention (Mean=3.54, $\mathrm{SD}=0.36$ ) and Relevance (Mean=3.51, $\mathrm{SD}=0.50$ ). Next, the Confidence construct obtained a mean value of $3.46(\mathrm{SD}=0.45)$ and the construct with the lowest mean value was Volition with mean=3.35 $(\mathrm{SD}=0.50)$. and normally distributed. ARCS model proposed five categories of motivation which are Very Good category (range from 4.50-5.00), Good category (range from 3.50-4.49), Quite Good category (range from 2.50-3.49), Less Good category (range from 1.50-2.49) and Not Good category (range from 1.00-1.49) (Jamil et al., 2019). Based on the proposed category, the majority of the constructs were in the good category with a range from 3.5-4.4.9; Satisfaction $=3.64$, Attention $=3.54$ and Relevance $=3.51$, the majority of the constructs were in the Good category with a range from 3.5-4.4.9. The overall reliability of all the scales on standardized Cronbach Alpha was $0.775(n=30)$ which suggested good reliability of items as acknowledged by Chang and Chen (2015) and Huang and Hew (2016).

Additionally, a series of pre and post-tests were conducted on 40 participants to assess whether there are any improvements in pupils' vocabulary learning. The assumption and conditions for the test were assessed. Participants were tested on the spelling of the new words introduced, their association with pictures as well as applying the vocabulary in sentences. The topics for each unit are as follows: Unit 1: Family Day, Unit 2: Saving, Sharing and Spending, Unit 3: Superheroes, Unit 6: Self Protection, Unit 7: The King's Decision and Unit 11: Natural Disasters. A 
paired or correlated sample t-test indicated that the post-test unit 1 to unit 7 and unit 11 had on average significantly improved on vocabulary score after using WOW as vocabulary learning tool than pre-test unit 1 to unit 7 and unit $11, t$ $(39)=-14.29, p<.001, d=20.39, t(39)=-14.64, p<.001, d=106.38, t(39)=-16.47, p<.001, d=48.25, t(39)=-$ $16.92, p<.001, d=6.66, t(39)=-11.15, p<.001, d=18.38, t(39)=-17.92, p<.001, d=9.36$ respectively. All paired sample t-test effect size was computed using WebPower's (2021) effect size calculator shows much larger than typical based on Cohen's (1988) guidelines for effects in the behavioural sciences.

\section{DISCUSSION}

The WOW interactive vocabulary game, as an external stimulus, contributes to the increase in scores between the series of pre and post-tests. The study proves that mobile phone application in learning increases pupils' comprehension and understanding of vocabulary as cited in Govindasamy et al. (2019) and Paulus et al. (2017). The vocabulary can be found in the form of images and the pronunciation of the word can be listened and seen in the form of audio or video which is also in line with Alnatour and Hijazi (2018). The use of online games promotes engagement via repetition contributes to a deeper understanding of the vocabulary and the ability to recall spelling easily. This is similar to a past study that supported the positive and long-lasting effect of online game learning on pupils' motivation (Darmi \& Albion, 2017).

This research highlights two significant challenges for pupils in incorporating WOW online games which are the limited number of mobile devices to access WOW and a stable internet connection. Pupils use their devices to access WOW at home. However, it is a challenging experience for some pupils who are from poor families due to inability to purchase mobile data and mobile phones. Acknowledging the issues, stakeholders, such as schools and parent teacher associations shall take the necessary steps to improve the pupils' learning experience by providing sufficient devices and internet connection through the optimization of the school's facilities. The school in the study has a problem with low maintenance and support of the internet and computers which prompted the researchers to conduct this study by integrating WOW as supplementary materials to be used at home.

Year 5 pupils had high Satisfaction, Attention, and Relevance motivation. However, their Confidence and Volition were at a moderate level. The results could educate pupils on utilizing various tools to enhance learning, such as online educational games in mobile applications and awareness. These findings could provide information on the necessity to design online educational games in line with the national syllabus. The WOW online games provide a positive learning experience, multiple game types, scores, and challenges. It was also found to amplify intrinsic motivation and persistence to achieve desired goals and ranks through healthy competition promoted in games. Self-directed learning is one of the skills highlighted in Education 4.0 as it facilitates independent learning via technology-enhanced educational tools as suggested by Min and Nasir (2020). Indirectly, this application can be used as supplementary or revision materials for Year 5.

In essence, educators need to embrace the technology-immersed classroom to cater to the current generation inclination towards technology-enhanced learning. Simultaneously, there is a great need to employ the appropriate online game-based learning that adheres to the national syllabus and outlined standards to provide easy integration of the innovations and pedagogical focus in the education system (Purgina et al., 2016). The study is limited to the development of the English vocabulary of the Year 5 KSSR syllabus. Other than that, this study only measured pupils' views of online vocabulary games on one platform. Hence, pupils' perceptions could not be generalised towards other English vocabulary online games. Exposing learners to multiple online games may require better resources and a longer time for the researchers to produce games on multiple virtual platforms that is of similar standard based on the national syllabus.

\section{ACKNOWLEDGEMENTS}

This research and publication is funded by Dana Khas Penyelidikan FPEND Covid-19 (GG-2020-021)

\section{REFERENCES}

[1] Adams, D., Sumintono, B., Mohamed, A. \& Nur Syafika Mohamad Noor. (2018). E-learning readiness among learners of diverse backgrounds in a leading Malaysian higher education institution. Malaysian Journal of Learning and Instruction 15(2): 227-256.

[2] Afzal, N. (2019). A study on vocabulary-learning problems encountered by BA English majors at the university level of education. Arab World English Journal, 10(3): 81-98. doi:10.24093/awej/vol10no3.6.

[3] Alnatour, A. S. \& Hijazi, D. (2018). The impact of using electronic games on teaching English vocabulary for kindergarten learners. US-China Foreign Language, 16(4): 193-205. doi:10.17265/1539-8080/2018.04.001.

[4] Alqahtani, M. (2015). The importance of vocabulary in language learning and how to be taught. International Journal of Teaching and Education, 3(3): 21-34. doi:10.20472/te.2015.3.3.002.

[5] Andreani, W. \& Ying, Y. (2019). "PowPow" interactive game in supporting English vocabulary learning for elementary learners. Procedia Computer Science, 157: 473-478. doi:10.1016/j.procs.2019.09.005.

[6] Ashrafzadeh, A. \& Nimehchisalem, V. (2015). Vocabulary knowledge: Malaysian tertiary level learners' major problem in summary writing. Journal of Language Teaching and Research. 6(2): 286. doi:10.17507/jltr.0602.07. 
[7] Azli, W. U. A., Shah, P. M., \& Mohamad, M. (2018). Perception on the Usage of Mobile Assisted Language Learning (MALL) in English as a Second Language (ESL) Learning among Vocational College Students. Creative Education, 9(1), 84-98. https://doi.org/10.4236/ce.2018.91008.

[8] Bakhsh, S. A. (2016). Using games as a tool in teaching vocabulary to young learners. English Language Teaching Journal, 9(7): 120. doi:10.5539/eltv9n7p120.

[9] Chang, N. C. \& Chen, H. H. (2015). A motivational analysis of the ARCS model for information literacy courses in a blended learning environment. Libri. 65(2): 129-142. doi:10.1515/libri-2015-0010.

[10] Chapman, J. R. \& Rich, P. J. (2018). Does educational gamification improve learners' motivation? Journal of Education for Business 93(7): 314-321. doi:10.1080/08832323.2018.1490687.

[11] Chen, Z., \& Lee, S. (2018). Application-driven educational game to assist young children in learning English vocabulary. Journal of Educational Technology \& Society, 21(1), 70-81.

[12] Chong, J. \& Kee, L. L. (2019). Using vocabulary journals to improve vocabulary learning among primary school pupils in Malaysia. Journal of English Education. 4(2): 108-120.

[13] Darmi, R., \& Albion, P. (2017). Enhancing oral communication skills using mobile phones among undergraduate English language learners in Malaysia. In Murphy, A., Farley, H. S., Dyson, L. E. \& Jones, H. (ed.). Mobile Learning in Higher Education in the Asia-Pacific Region: Issues, Concerns and Prospects, 297-314. Singapore: Springer Nature. https://doi.org/10.1007/978-981-10-4944-.

[14] Daud, R., Jalil, Z. A., \& M. Gunawan, M. N. F. (2015). Community college students' perception towards digital learning In Malaysia. Procedia- Social and Behavioral Sciences, 195, 1798-1802. https://doi.org/10.1016/j.sbspro.2015.06.389.

[15] Deris, F. D., \& Shukor, N. S. A. (2019). Vocabulary learning through mobile apps: A phenomenological inquiry of student acceptance and desired apps features. International Journal of Interactive Mobile Technologies, 13(7), 129-140. https://doi.org/10.3991/ijim.v13i07.10845.

[16] Fagan, M. H. (2019). Factors influencing student acceptance of mobile learning in higher education. Journal of Computers in Education 36(2): 105-121. doi:10.1080/07380569.2019.1603051.

[17] Fazil, K. F. \& Said, N. E. M. (2020). A Grammar-learning innovation for Malaysian Indigenous learners in an EFL context: The TurTense mobile game app. International Journal of Academic Research in Progressive Education \& Development, 9(1), 220-235. https://doi.org/10.6007/IJARPED/v9-i1/6997.

[18] Gangaiamaran, R. \& Pasupathi, M. (2017). Review on the use of mobile apps for language learning. International Journal of Applied Engineering Research. 12(21): 11242-11251.

[19] Govindasamy, P., Yunus, M. M., \& Hashim, H. (2019). Mobile assisted vocabulary learning: Examining the effects on students' vocabulary enhancement. Universal Journal of Educational Research, 7(12), 85-92. https://doi.org/10.13189/ujer.2019.071911.

[20] Hashim, H., Md. Yunus, M., Amin Embi, M., \& Mohamed Ozir, N. A. (2017). Mobile-assisted Language Learning (MALL) for ESL Learners: A Review of affordances and constraints. Sains Humanika, 9(1-5). https://doi.org/10.11113/sh.v9n1-5.1175.

[21] Hasin, I., \& Nasir, M. K. M. (2021). The Effectiveness of the Use of Information and Communication Technology (ICT) in Rural Secondary Schools in Malaysia. Journal of Education and e-Learning Research, 8(1): 59-64. doi:10.20448/journal.509.2021.81.59.64.

[22] Huang, B. \& Hew, K. F. (2016). Measuring learners' motivation level in Massive Open Online Courses (MOOC). International Journal of Information and Education Technology. 6(10): 759-764.

[23] Jamil, M. M., Ningrum, E. \& Yani, A. (2019). Level of learning motivation student based on ARCS Model on Geographic subject. IOP Conference Series: Earth and Environmental Science. 286(1). doi:10.1088/1755-1315/286/1/012010.

[24] Jantke, K. P. \& Hume, T. (2015). Effective Learning through meaning construction in digital role-playing games. International Conference on Consumer Electronics (March 2015): 653-656.

[25] Karim, R. A., Abu, G. A., Haimi, A., Adnan, M., Dwi, A., \& Suhandoko, J. (2018). The use of mobile technology in promoting Education 4.0 for Higher Education. Advanced Journal of Technical and Vocational Education, 2(3), 34-39. https://doi.org/10.26666/rmp.ajtve.2018.3.6.

[26] Keller, J. M. (2016). Motivation, learning, and technology: Applying the ARCS-V motivation model. Participatory Educational Research. 3(2): 1-15. doi:10.17275/per.16.06.3.2.

[27] Kessler, G. (2018). Technology and the future of language teaching. Foreign Language Annals. 51(1), 205-218. doi: https://doi.org/10.1111/flan.12318.

[28] Klimova, B. (2019). Impact of mobile learning on learners' achievement results. Education Sciences. 9(2). https://doi:10.3390/educsci9020090 .

[29] Kumi-Yeboah, A., Yuan, G. \& Dogbey, J. (2017). Online collaborative learning activities: The perceptions of culturally diverse graduate learners. Online Learning Journal, 21(4): 5-28. https://doi:10.24059/olj.v21i4.1277.

[30] Kung-Teck, W., Muhammad, M., Abdullah, N., \& Hamdan, A. (2020). Mobile-heutagogical practices among student teachers: Its pedagogical affordances and challenges. International Journal of Interactive Mobile Technologies, 14(2), 130-143. https://doi.org/10.3991/ijim.v14i02.11819.

[31] Lateh, N. H. M., Shamsudin, S., \& Abdul Raof, A. H. (2018). Receptive vocabulary levels of Malaysian university students. LSP International Journal, 5(1), 105-113. https://doi.org/10.11113/lspi.v5n1.68.

[32] Letchumanan, K., Tan, B. H., Paramasivam, S., Rashid, S. M. \& Muthusamy, P. (2015). Incidental learning of vocabulary through computer-based and paper-based games by secondary school ESL learners. Pertanika Journal of Social Science and Humanities. 23(3): 725-740.

[33] Min, H., \& Nasir, M. K. M. (2020). Self-Regulated Learning In A Massive Open Online Course: A Review of Literature. European Journal of Interactive Multimedia and Education, 1(2), e02007. https://doi.org/10.30935/ejimed/8403.

[34] Mohamad, M., Arif, F. K. M., Alias, B. S., \& Yunus, M. M. (2020). Online game-based formative assessment: Distant learners post graduate students' challenges towards Quizizz. International Journal of Scientific and Technology Research, 9(4), 9941000 . 
[35] Mohamad, S. N. M., Sazali, N. S. S., \& Salleh, M. A. M. (2018). Gamification approach in Education to increase learning engagement. International Journal of Humanities, Arts and Social Sciences, 4(1), 22-32. https://doi.org/10.20469/ijhss.4.10003-1.

[36] Nasir., M. K. N., Mansor, A. Z., \& Rahman, M. J. A. (2018). Measuring Malaysian online university student social presence in an online course offered. Journal of Advanced Research in Dynamical and Control Systems, 10(12), 1442 - 1446.

[37] Nasir, M. K. M. (2020). The Influence of Social Presence on Students' Satisfaction toward Online Course. Open Praxis, 12(4), 485-493. https://doi.org/10.5944/openpraxis.12.4.1141.

[38] Nejati, E. \& Jahangiri, A. (2018). The effect of using computer-assisted language learning (CALL) on Iranian EFL learners' vocabulary learning: An experimental study. Cypriot Journal of Educational Sciences, 13(2): 113-124. https://doi:10.18844/cjes.v13i2.752.

[39] Niko Sudibjo, Lusiana Idawati, \& HG Retno Harsanti. (2019). Characteristics of learning in the era of Industry 4.0 and Society 5.0. Proceedings of the International Conference on Education Technology (ICoET), September 2019: 276-278.

[40] Paulus, M., Marron, E. M., Viejo-Sobera, R., \& Redolar-Ripoll, D. (2017). Neural basis of video gaming: A systematic review. Frontiers in Human Neuroscience, 11(248), 1-40 https://doi.org/10.3389/fnhum.2017.00248 (accessed 17/3/2020).

[41] Perrin, A. \& Duggan, M. (2015). Americans' Internet access: 2000-2015. Pew Research Center (June 2015): 1-13.

[42] Purgina, M., Mozgovoy, M. \& Ward, M. (2017). MALL with WordBricks: Building correct sentences brick by brick. Computer Science: $254-259$. https://doi:10.14705/rpnet.2017.eurocall2017.722.

[43] Sidek, H. M. \& Rahim, H. A. (2015). The Role of Vocabulary Knowledge in Reading Comprehension: A Cross-Linguistic Study. Procedia - Social and Behavioral Sciences 197(February): 50-56. https://doi:10.1016/j.sbspro.2015.07.046.

[44] Takahashi, D. (2010). Gamification Gets its Own Conference. Venturebeat. http://venturebeat.com/2010/09/30/gamificationgets-its-own-conference/ (accessed 28/4/2020).

[45] Tanaka, M. (2017). Examining EFL vocabulary learning motivation in a demotivating learning environment. System 65: 130138. https://doi:10.1016/j.system.2017.01.010.

[46] Tang, J. (2015). Family Socioeconomic Status and Personal Media Technology Use. Murfreesboro, TN: Middle Tennessee State University.

[47] Tankari, M. (2018). Cultural Orientation Differences and Their Implications for Online Learning Satisfaction. In Technology Adoption and Social Issues: Concepts, Methodologies, Tools, and Applications, pp. 505 - 554. Pennsylvania: IGI Global.

[48] Thamilarasan, Y., \& Ikram, R. R. R. (2019). MyMUET: A design of a mobile based crowdsourced assessment for Malaysia university English test with non-synchronous participant interaction. International Journal of Innovative Technology and Exploring Engineering, 8(11), 2971-2977. https://doi.org/10.35940/ijitee.K2277.0981119.

[49] Wang, F. \& Yamat, H. (2019). Identifying English vocabulary levels of Malaysia year 5 primary school learners. International Journal of Academic Research in Business and Social Sciences 9(12): 62-76. https://doi:10.6007/JJARBSS/v9-i12/6669.

[50] WebPower's. (2021). WebPower. Statistical Power https://webpower.psychstat.org/models/means01/effectsize.php (accessed 13/5/2020).

[51] Zakaria, Y., Mohamad, M. \& Idris, F. (2019). Language camp in Malaysia: Asnaf students' needs and perception. Humanities and Social Sciences Reviews, 7(2), 287-295. https://doi.org/10.18510/hssr.2019.7234.

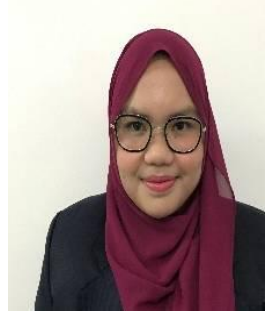

Syafiqah Hasram was born in Negeri Sembilan on December 16th, 1993. The author obtained her Bachelor of Teaching (Hons) Teaching of English as a Second Language for Primary Education in a teacher education institution Malacca campus, Malaysia in 2016. Previously she worked as substitute teachers, camp counsellors and joined several volunteering programmes teaching English to children of the Indigenous communities, around Selangor and Negeri Sembilan. She is currently working at a national primary school in Mantin, Negeri Sembilan while pursuing Master's part time. The author has mainly published journal articles online. The author's area of interest includes the integration of technology in English language learning and how it affects academic performance.

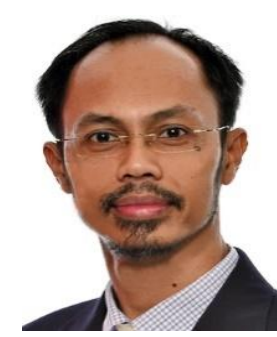

M. Khalid M. Nasir (Ph.D) is currently a Senior Lecturer and a media coordinator at the Faculty of Education Universiti Kebangsaan Malaysia (UKM). He Graduated from University Technology MARA (UiTM), for his Diploma in Land Surveying (Surveying Sciences \& Geomatics Engineering) and Bachelor of Education in Information Technology (IT) with Honours at Universiti Utara Malaysia (UUM). His Master of Education in Instructional Technology at International Islamic University Malaysia (IIUM). He received his Doctor of Philosophy in Education \& Human Resource Studies (Instructional Technology) from Colorado State University, USA. His area of specialization in Computer Education, Educational Technology, Instructional Technology \& Community of Inquiry (CoI) in Online learning. He is also a Certified Professional Technologist as acknowledged by Malaysian Board of Technologists (MBOT) in the field of Information \& Computing Technology (IT) and currently appointed as Master Trainer by Malaysia Digital Economy Corporation (MDEC). 


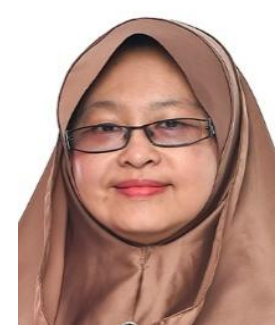

Maslawati Mohamad (Ph.D) was born in Johor, Malaysia. Currently, she is a senior lecturer at Faculty of Education, Universiti Kebangsaan Malaysia. Her main research interests are innovations in teaching and learning in ESL context, Teaching Reading in ESL context and English for Specific Purposes. Currently she has published 101 journal articles including 30 Scopus articles, 55 proceedings, six book chapters and a book. She is also a reviewer for a few international journals and editor for a local journal. She graduated from Universiti Kebangsaan Malaysia and her area of specialization is Teaching English as a Second Language. She had also presented her research output locally and internationally in various seminars and conferences.

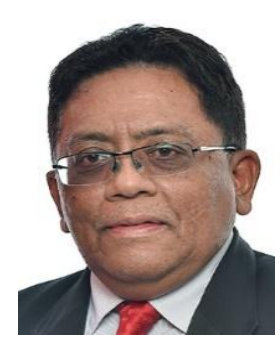

Md Yusoff Daud was born in Kota Bharu, Kelantan. He is currently working as a senior lecturer at the Center of Innovation in Teaching and Learning, Faculty of Education, UKM since 2000 until now. He graduated from Universiti Kebangsaan Malaysia (UKM) in Bachelor of Science (Honours) and Master of Education (ICT). His specialization was in the field of integration of ICT in teaching and learning. The job scope includes teaching, supervising and writing books and journal articles. Until now, he had actively produced many journals, articles and books related to ICT cross discipline taught in schools and also in the higher education level. Moreover, he had also presented his research output locally and internationally in various seminars and conferences.

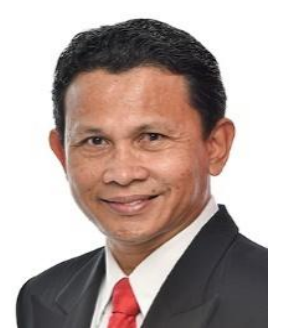

Mohd Jasmy Abd Rahman was born in Mersing, Johor in 1969. He is a Senior Lecturer at the Faculty of Education, UKM since 1998 until now. He specializes in the field of multimedia in education and has produced many journals, articles and books related to instructional technology in many disciplines taught in schools or at the higher education level. He is also very active in the field of Co-Curriculum and has been appointed as the Director of the Kesatria-UKM, center to coordinate the activities of the Uniformed Force. Among the books he has produced such as Information Technology Promotion and Marketing: 21st Century Empowerment (2015), ICT in Teaching and Learning (2016), Social Media: 21st Century Learning (2016) Photography: Fieldwork Figures (2016), Medic Lens (2016), Sociology of Education: Sarawak Perspective (2016), Multimedia in Islamic Education (2017), Innovation in the Military (2017). Techno Media Promotion (2017), IT in 21st Century Education, Drones in Education: A Collection of Empirical Studies (2018), Issues in Education Vol. 2 (2018), Academic Writing Course Guide (2018), i-Sprint Applications in Co-curriculum (2018), Teachers and Education Issues (2019), Academic Bio Lens Vol. 2 (2019), Innovation in the Military Vol. 2 (2019), Innovation in the Military Vol. 3 (2020) Digital Education Era RI 4.0 (2020), Academic Bio Lens Vol. 3 (2020) as well as the writing of chapters in books.

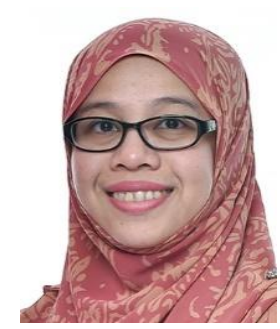

Wan Muna Ruzanna Wan Mohammad (Ph.D) was born in Terengganu, Malaysia. Currently, she is a senior lecturer at Faculty of Education, Universiti Kebangsaan Malaysia. Her area is Language and Malay Linguistics, Psycholinguistics, Dyslexia, Malay Language in Education) She is involved in conducting researches in this area and published a number of journal articles. Her PhD is from Universiti Putra Malaysia. 